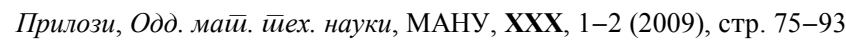
Contributions, Sec. Math. Tech. Sci., MANU, XXX, 1-2 (2009), pp. 75-90

ISSN 0351-3246

UDC: $512.541 .5: 512.548 .7$

Original scientific paper

\title{
QUASIGROUPS CONSTRUCTED FROM COMPLETE MAPPINGS OF A GROUP $\left(\mathrm{Z}_{2}^{n}, \oplus\right)$
}

\author{
Aleksandra Mileva, Vesna Dimitrova
}

A b s t r a c t: The quasigroups constructed from complete mappings of a group $\left(Z_{2}^{n} \oplus\right)$ in a term of their properties like: satisfying the associative, commutative and idempotent law, having proper subquasigroups, having left or right unit, their representation with ANF, their prop ratio tables and correlation matrices and satisfying some other identities are examined in this paper. This is important for their applicability in cryptography, coding theory and other fields. As an example, we give quasigroups constructed from 384 complete mappings of a group $\left(Z_{2}^{3}, \oplus\right)$.

Key words: quasigroup; complete mapping; TA-quasigroup

\section{INTRODUCTION}

There are many different ways of constructing quasigroups. One can construct a quasigroup by isotopies and/or their combination with Feistel network [12], with T-functions (special type of functions defined by Klimov and Shamir [9]), with diagonal method by complete mappings [15], with direct or quasi-direct product of smaller quasigroups [3, 17], (generalized) singular direct product $[10,16]$ etc.

In this paper are examined the quasigroups constructed by Sade's diagonal method from complete mappings of the group $\left(\mathrm{Z}_{2}^{n}, \oplus\right)$, and specially, of 
the group $\left(\mathrm{Z}_{2}^{3}, \oplus\right)$. There are 384 such quasigroups. In Section 2 are given some basic mathematical definition for quasigroups and complete mappings. Definition of prop ratio tables and correlation matrices are given in Section 3. Some propositions about constructed quasigroups are presented in Section 4. In Section 5 are shown a special case of quasigroups constructed from complete mappings of a group $\left(\mathrm{Z}_{2}^{3}, \oplus\right)$. List of all complete mappings of group $\left(\mathrm{Z}_{2}^{3}, \oplus\right)$ are given in Appendix $\mathrm{A}$ and corresponding quasigroups (in ANF) constructed from complete mappings of a group $\left(\mathrm{Z}_{2}^{3}, \oplus\right)$ in Appendix B.

\section{QUASIGROUPS AND COMPLETE MAPPINGS}

Definition 2.1. Let * be a binary operation on $Q$. The groupoid $\left(Q,{ }^{*}\right)$ is a quasigroup if the following law is satisfied:

$$
\forall \mathrm{a}, \mathrm{b} \in \mathrm{Q})(\exists ! \mathrm{x}, \mathrm{y} \in \mathrm{Q})\left(\mathrm{a} * \mathrm{x}=\mathrm{y}^{*} \mathrm{a}=\mathrm{b}\right)
$$

Related combinatorial structures to finite quasigroups are the Latin squares, since the main body of the multiplication table of a quasigroup is a Latin square [1].

Quasigroup $\left(Q,{ }^{*}\right)$ have a proper subquasigroup $H$, if $H \subset Q$, and $(H, *)$ is a quasigroup.

Definition 2.2 A complete mapping of a group $(\mathrm{G},+)$ is a bijection $\theta: G \rightarrow G$ such that the mapping $\phi: G \rightarrow G$ defined by $\phi(x)=-x+\theta(x)(\phi=-I+\theta$, where $I$ is the identity mapping) is also a bijection of $G$. The mapping $\phi$ is said to be the orthomorphism associated to complete mapping $\theta$.

A group $G$ is admissible if there is a complete mapping $\theta: G \rightarrow G$. Some properties about admissible groups are given in $[8,13,14]$.

Proposition 2.1 Let $(G,+)$ be a group and let $\theta: G \rightarrow G$ be a bijection. If $\theta(x)=x$ and $\theta(y)=y$ for some $x \neq y \in G$, then $\theta$ is not a complete mapping of $(G,+)$.

Proof. Let $\theta(x)=x$ and $\theta(y)=y$ for some $x \neq y \in G$ and let $\phi: G \rightarrow G$ be defined as $\phi(x)=-x+\theta(x)$. Then $\phi$ is not a bijection, because $\phi(x)=0$ and $\phi(y)$ $=0$. This implies that $\theta$ is not a complete mapping of $(G,+)$. 
The method for creating a quasigroup from an admissible group is proposed by Sade [15]:

Proposition 2.2 Let $(Q,+)$ be an admissible group with complete mapping $\theta$. If * is an operation on $Q$ defined by

$$
x * \mathrm{y}=\theta(x-y)+y,
$$

where $x, y \in Q$, then $\left(Q,{ }^{*}\right)$ is a quasigroup.

In this paper are considered only complete mappings of the Abelian group $\left(\mathrm{Z}_{2}^{n}, \oplus_{n}\right)$, where $\oplus_{\mathrm{n}}$ is bitwise XOR operation on words with $n$ bits. For this group the operation $*$ is defined as:

$$
x * y=\theta\left(x \oplus_{n} y\right) \oplus_{n} y
$$

Definition 2.3 Let $(G,+)$ be a group. The mapping $f: G \rightarrow G$ is an affine mapping if $f(x+y)=f(x)+f(y)-f(0)$ for each $x, y \in G$, where $0 \in G$ is the identity element. A linear mapping is an affine mapping $f$ with $f(0)=0$.

In the following, we give some definitions for special kind of quasigroups

Definition 2.4 A quasigroup $(Q, *)$ is called Shroeder quasigroup if it satisfy the identity

$$
(x * y) *(y * x)=x
$$

for all $x, y \in Q$.

Definition 2.5 A quasigroup $\left(Q,{ }^{*}\right)$ is called totally anti-symmetric (TA-quasigroup) if it satisfy the following implications

$$
\begin{gathered}
(1)(c * x) * y=(c * y) * x \Rightarrow x=y, \\
(2) x * y=y * x \Rightarrow x=y
\end{gathered}
$$

for all $c, x, y \in Q$. 
The quasigroup that satisfies only the first implication is called weak totally anti-symmetric (WTA-quasigroup).

TA-quasigroups are used in check digit systems for recognizing early typing errors [6]. Let $\left(Q,{ }^{*}\right)$ be a quasigroup and let $d_{m} d_{m-1} \ldots d_{1}$ be a given number. The check digit is defined to be the unique solution $d_{0}$ of the equation

$$
\left(\left(\ldots\left(\left(d_{m} * d_{m-1}\right) * d_{m-2}\right) * \ldots\right) * d_{1}\right) * d_{0}=0
$$

The cancellation laws and the TA property guarantee the detection of the two most frequent errors: the single errors $(\ldots a \ldots \rightarrow \ldots b \ldots)$ and the transposition errors $(\ldots a b \ldots \rightarrow \ldots b a \ldots)$.

\section{CORRELATION MATRICES AND PROP RATIO TABLES}

A Boolean function $f$ is a function $f: Z_{2}^{n} \rightarrow Z_{2}$. A vector-valued Boolean function $h$ is a mapping $h: Z_{2}^{n} \rightarrow Z_{2}^{m}$ and it can be decomposed into $m$ component Boolean functions $\left(h_{0}, h_{1}, \ldots, h_{m-1}\right)$. Quasigroups can be examined as vector valued Boolean function. For example, if $(Q, *)$ is a quasigroup of order 8 then it can be represented as vector-valued Boolean function $h: Z_{2}^{6} \rightarrow Z_{2}^{3}$ where $\left(x_{0}, x_{1}, x_{2}\right),\left(x_{3}, x_{4}, x_{5}\right),\left(y_{0}, y_{1}, y_{2}\right) \in Q=\mathrm{Z}_{2}^{3}$ and

$$
h\left(x_{0}, x_{1}, x_{2}, x_{3}, x_{4}, x_{5}\right)=\left(x_{0}, x_{1}, x_{2}\right) *\left(x_{3}, x_{4}, x_{5}\right)=\left(y_{0}, y_{1}, y_{2}\right)
$$

The correlation matrix of a vector-valued Boolean function is a useful concept [5] for proving some properties of Boolean functions and mappings. The elements of the correlation matrices are the correlation coefficients associated with linear combinations of input bits and linear combinations of output bits. Linear cryptanalysis [11] can be seen as the exploitation of correlations between linear combinations of bits of different intermediate encryption values in a block cipher calculation. So, correlation matrices can be used for understanding the mechanisms of linear cryptanalysis.

Definition 3.1 The correlation coefficient associated with a pair of Boolean functions $f(a)$ and $g(a)$ is denoted by $C(f, g)$ and it is given by 


$$
C(f, g)=2 P[f(a)=g(a)]-1
$$

where $\mathrm{P}$ is probability of $f(a)=g(a)$. The correlation coefficient range is between -1 and 1 . If it is different from 0 , the functions are said to be correlated.

A selection vector $w$ is a binary vector that selects all components $i$ of a vector $a$ where $w_{i}=1$. For example, the selection vector $(1,0,1)$ selects the bits $a_{0}$ and $a_{2}$ from vector $a=\left(a_{0}, a_{1}, a_{2}\right) . w^{T} a$ represents the linear combination of the components of a vector $a$ selected by $w$. All correlation coefficients between linear combinations of input bits and output bits of the mapping $h$ can be arranged in a correlation $2^{m} \times 2^{n}$ - matrix $C^{h}$. $C_{u w}$ is the element in the $u$-row and the $w$-column and it is equal to $C\left(u^{T} h(a), w^{T} a\right)$. The rows in this matrix can be interpreted as

$$
(-1)^{u^{T} h(a)}=\sum_{w} C_{u w}^{h}(-1)^{w^{T} a} .
$$

This means that the real-valued function corresponding to a linear combination of output bits can be written as a linear combination of the real-valued functions corresponding to a linear combination of input bits.

Other useful concept of the Boolean functions and mappings are prop ratio tables [4]. This concept is important for differential cryptanalysis [2]. Let $a$ and $a^{*}$ be $n$-bit vectors with bitwise difference $a+a^{*}=a^{\prime}$. Let $b=h(a), b^{*}=$ $h\left(a^{*}\right)$ and $b^{\prime}=b+b^{*}$. Hence, the difference $a^{\prime}$ propagates the difference $b^{\prime}$ through mapping $h$ and this can be represented by $\left(a^{\prime} \nmid h+b^{\prime}\right)$.

Definition 3.2 The prop ratio $R_{p}$ of a difference propagation $\left(a^{\prime} \dashv h\right.$ $\left.{ }^{\prime} b^{\prime}\right)$ is given by

$$
R p\left(a^{\prime} \dashv h \vdash b^{\prime}\right)=2^{-n} \sum_{a} \delta\left(b^{\prime}+h\left(a+a^{\prime}\right)+h(a)\right)
$$

where $\delta(w)$ is the real-valued function equal to 1 if $w$ is the zero vector and 0 otherwise.

The prop ratio range is between 0 and 1 . If a pair is chosen uniformly from the set of all pairs $\left(a, a^{*}\right)$ with $a+a^{*}=a^{\prime}$, the equality $h(a)+h\left(a^{*}\right)=b^{\text {' }}$ is true with some probability. It is clear that $\sum_{b} R_{p}\left(a^{\prime}-h^{\prime} h-b^{\prime}\right)=1$.

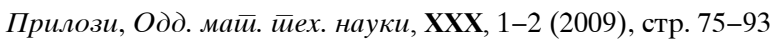




\section{ANALYSIS OF QUASIGROUPS CONSTRUCTED FROM COMPLETE MAPPINGS OF THE GROUP $\left(\mathrm{Z}_{2}^{n}, \oplus_{n}\right)$}

Some properties like associability, commutability, the idempotent law, having left or right unit and satisfying some identities for quasigroups constructed from complete mappings of the group $\left(\mathrm{Z}_{2}^{n}, \oplus_{n}\right)$ are examined. Specially, for quasigroups constructed from complete mappings of the group $\left(\mathrm{Z}_{2}^{3}, \oplus_{3}\right)$, are examined their prop ratio tables, correlation matrices, their representation with ANF (Algebric Normal Form) and do they have proper subquasigoup.

Proposition 4.1 The quasigroup $\left(Q,{ }^{*}\right)$, constructed by a complete mapping $\theta$ of the group $\left(\mathrm{Z}_{2}^{n}, \oplus_{n}\right)$ with operation * defined by equation (2) is a Shroeder quasigroup.

Proof. If $x, y \in Q$, then

$$
\begin{aligned}
(x * y) *(y * x)= & \left(\theta\left(x \oplus_{n} y\right) \oplus_{n} y\right) *\left(\theta\left(y \oplus_{n} x\right) \oplus_{n} x\right)= \\
& \theta\left(\theta\left(x \oplus_{n} y\right) \oplus_{n} y \oplus_{n} \theta\left(y \oplus_{n} x\right) \oplus_{n} x\right) \oplus_{n} \theta\left(y \oplus_{n} x\right) \oplus_{n} x= \\
& \theta\left(y \oplus_{n} x\right) \oplus_{n} \theta\left(y \oplus_{n} x\right) \oplus_{n} x=x .
\end{aligned}
$$

Proposition 4.2 The quasigroup $(Q, *)$, constructed by a complete mapping $\theta$ of the group $\left(\mathrm{Z}_{2}^{n}, \oplus_{n}\right)$ is anti-commutative quasigroup. $*(x * y)=y$.

Proof. Let $x, y \in Q$ and $x * y=y * x$. Then $x=(x * y) *(y * x)=(y * x)$

Proposition 4.3 The quasigroup $\left(Q,{ }^{*}\right)$, constructed by an affine complete mapping $\theta$ of the group $\left(\mathrm{Z}_{2}^{n}, \oplus_{n}\right)$ is a TA-quasigroup. tion too.

Proof. Let $\phi=I \oplus_{\mathrm{n}} \theta$ be (is) orthomorphism of $\theta$, so $\phi$ is affine bijec-

$$
\begin{gathered}
\text { If } x, y, c \in Q \text { and }(c * x) * y=(c * y) * x \text {, then } \\
\theta\left(\theta\left(c \oplus_{\mathrm{n}} x\right) \oplus_{\mathrm{n}} x \oplus_{\mathrm{n}} y\right) \oplus_{\mathrm{n}} y=\theta\left(\theta\left(c \oplus_{\mathrm{n}} y\right) \oplus_{\mathrm{n}} y \oplus_{\mathrm{n}} x\right) \oplus_{\mathrm{n}} x \Rightarrow(\theta \text { is affine })
\end{gathered}
$$


$\theta\left(\theta\left(c \oplus_{n} x\right)\right) \oplus_{n} y=\theta(\theta(c \oplus n y)) \oplus n x \Rightarrow$

$\theta\left(\theta(c) \oplus_{n} \theta(x) \oplus_{n} \theta(0)\right) \oplus_{n} y=\theta\left(\theta(c) \oplus n \theta(y) \oplus_{n} \theta(0)\right) \oplus_{n} x \Rightarrow$

$\theta(\theta(x)) \oplus_{n} y=\theta(\theta(y)) \oplus_{n} x \Rightarrow$

$\theta(\theta(x)) \oplus_{n} \theta(x) \oplus_{n} \theta(x) \oplus_{n} x=\theta(\theta(y)) \oplus_{n} \theta(y) \oplus_{n} \theta(y) \oplus_{n} y \Rightarrow$

$\phi(\theta(x)) \oplus_{n} \phi(x) \oplus_{\mathrm{n}} \phi(0)=\phi(\theta(y)) \oplus_{n} \phi(y) \oplus_{n} \phi(0) \Rightarrow(\phi$ is affine $)$

$\phi\left(\theta(x) \oplus_{n} x\right)=\phi\left(\theta(y) \oplus_{n} y\right) \Rightarrow(\phi$ is bijection $)$

$\theta(x) \oplus_{n} x=\theta(y) \oplus_{n} y \Rightarrow$

$\phi(x)=\phi(y) \Rightarrow(\phi$ is bijection $) x=y$.

Proposition 4.2. implies that $Q$ is TA-quasigroup.

Proposition 4.4 The quasigroup $\left(Q,{ }^{*}\right)$, constructed by a complete mapping $\theta$ of the group $\left(\mathrm{Z}_{2}^{n}, \oplus_{n}\right)$ is idempotent quasigroup iff $\theta(0)=0$.

Proof. If $x \in Q$, then $x * x=x \Leftrightarrow \theta\left(x \oplus_{n} x\right) \oplus_{\mathrm{n}} x=x \Leftrightarrow \theta(0) \oplus_{n} x=$ $x \Leftrightarrow \theta(0)=0$.

Proposition 4.5 The quasigroup $\left(Q,{ }^{*}\right)$ constructed by a complete mapping $\theta$ of the group $\left(Z_{2}^{n}, \oplus_{n}\right)$ is without left or right unit.

Proof. Let $e$ be the right unit of $(Q, *)$. Then

$$
x^{*} e=x \Rightarrow \theta\left(x \oplus_{n} e\right) \oplus_{n} e=x \Rightarrow \theta\left(x \oplus_{n} e\right)=x \oplus_{n} e
$$

for all $x \in Q$. This means that $\theta=I$ is the identity mapping. This is contradiction with $\theta$ is a complete mapping of a $\left(Z_{2}^{n}, \oplus_{n}\right)$ (identity mapping isn't complete mapping of a $\left(Z_{2}^{n}, \oplus_{n}\right)$, from Proposition 2.1). So, $Q$ is without right unit.

Let $e$ be the left unit of $(Q, *)$. Then

$$
e^{*} x=x \Rightarrow \theta\left(e \oplus_{n} x\right) \oplus_{n} x=x \Rightarrow \theta\left(e \oplus_{n} x\right)=0
$$


for all $x \in Q$. This means that $\theta$ is a zero mapping. This is contradiction with $\theta$ is a bijection. So, $Q$ is without left unit.

Proposition 4.6 The quasigroup $(Q, *)$, constructed by a complete mapping $\theta$ of the group $\left(\mathrm{Z}_{2}^{n}, \oplus_{n}\right)$ is non-associative

Proof. Every associative quasigroup is a group, and every group possesses a unit element, so because of Proposition 4.5, the quasigroup $(Q, *)$ is non-associative.

Some "pairing" properties for quasigroup $(Q, *)$ constructed by affine complete mapping of a group $\left(\mathrm{Z}_{2}^{n}, \oplus_{n}\right)$ are defined and proved [12]. First "pairing" property tells us that every row in the multiplication table of $(Q, *)$ is the reversal of another row and every column of $(Q, *)$ is the reversal of another column. This can be defined as follows.

Definition 4.1 Let $(Q, *)$ be a quasigroup and $k, x, y \in Q$. Rows $x$ and $y$ are paired over $\boldsymbol{k}$ if for any $a, z \in Q$, whenever $a$ appears in row $x$, column $z, a$ also appears in row $y$, column $z+k$.

Definition 4.2 Let $(Q, *)$ be a quasigroup and let $k, x, y \in Q$. Columns $x$ and $y$ are paired over $\boldsymbol{k}$ if for any $a, z \in Q$, if $a$ appears in row $z$ and column $x$, then $a$ also appears in row $z+k$ and column $y$.

Proposition 4.7 [12] Let $(Q, *)$ be a quasigroup constructed from the group $\left(\mathrm{Z}_{2}^{n}, \oplus_{n}\right)$ by

$$
x^{*} y=\theta\left(x \oplus_{n} y\right) \oplus_{n} y
$$

where $\theta: Q \rightarrow Q$ is an affine complete mapping and $k, x, y \in Q$. Then rows $x$ and $y$ are paired over $k$ if and only if $x * k=\theta(y)$, i.e., for any $z \in Q$,

$$
x * z=y *\left(z \oplus_{n} k\right) \Leftrightarrow x * k=\theta(y) .
$$

Notice that for any $k, x \in Q$, there exists $y$, because the quasigroup equations have unique solutions. 
Similarly, columns $x$ and $y$ are paired over $k$ if and only if $k * x=\phi(y)$, where $\phi: Q \rightarrow Q$ is the orthomorphism of $\theta$, i.e., for any $z \in Q$,

$$
z * x=\left(z \oplus_{n} k\right) * y \Leftrightarrow k * x=\phi(y) .
$$

Another "pairing" property tells us that every element has its "pair" element that appear next to it in every row and every column in multiplication table of $(Q, *)$

\section{SPECIAL CASE - QUASIGROUPS CONSTRUCTED FROM COMPLETE MAPPINGS OF THE GROUP $\left(\mathrm{Z}_{2}^{3}, \oplus_{3}\right)$}

There are 384 complete mappings of the group $\left(Z_{2}^{3}, \oplus\right)$, given in Appendix A. All these mapping are affine mappings, and 48 of them are linear mappings.

With exhaustive search and examination in software package Matlab and with properties from Section 4, we have found that all 384 constructed quasigroups are non-associative, non-commutative, without left or right unit and without proper subquasigroup. All of them are Shoreder's quasigroups and TAquasigroups. 48 of them are idempotent quasigroups. Also, all of them have prop ratio table with one element 1 in every column and others elements 0 , and correlation matrix with one element 1 or -1 in every row and others elements 0 .

From their prop ratio tables and correlation matrices we can conclude that all 384 quasigroups are linear quasigroups [7]. If they are represented as vector valued Boolean functions, then every bit of the output is represented as affine function of input bits. The representation of all 384 quasigroups with ANF is given in Appendix B.

Example 1. Let $\theta: Q \rightarrow Q$ be a complete mapping given by the table below.

\begin{tabular}{c|c|c|c|c|c|c|c|c}
\hline$x$ & 0 & 1 & 2 & 3 & 4 & 5 & 6 & 7 \\
\hline$\theta(x)$ & 2 & 5 & 1 & 6 & 4 & 3 & 7 & 0 \\
\hline$\phi(x)$ & 2 & 4 & 3 & 5 & 0 & 6 & 1 & 7 \\
\hline
\end{tabular}

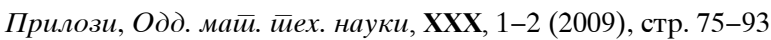


The corresponding quasigroup is given by the table

\begin{tabular}{c|cccccccc}
\hline \hline$*$ & 0 & 1 & 2 & 3 & 4 & 5 & 6 & 7 \\
\hline 0 & 2 & 4 & 3 & 5 & 0 & 6 & 1 & 7 \\
1 & 5 & 3 & 4 & 2 & 7 & 1 & 6 & 0 \\
2 & 1 & 7 & 0 & 6 & 3 & 5 & 2 & 4 \\
3 & 6 & 0 & 7 & 1 & 4 & 2 & 5 & 3 \\
4 & 4 & 2 & 5 & 3 & 6 & 0 & 7 & 1 \\
5 & 3 & 5 & 2 & 4 & 1 & 7 & 0 & 6 \\
6 & 7 & 1 & 6 & 0 & 5 & 3 & 4 & 2 \\
7 & 0 & 6 & 1 & 7 & 2 & 4 & 3 & 5 \\
\hline \hline
\end{tabular}

The prop ratio table of this quasigroup is:

\begin{tabular}{l|lllllllllllllllllllllllllllllllllllll}
\hline \hline & 0 & 1 & 2 & 3 & 4 & 5 & 6 & 7 & 8 & 9 & 10 & 11 & 12 & 13 & 14 & 15 & 16 & 17 & 18 & 19 & 20 & 21 & 22 & 23 & 24 & 25 & 26 & 27 & 28 & 29 & 30 & 31 \\
\hline 0 & 1 & 0 & 0 & 0 & 0 & 0 & 0 & 0 & 0 & 0 & 0 & 1 & 0 & 0 & 0 & 0 & 0 & 0 & 0 & 0 & 0 & 0 & 1 & 0 & 0 & 0 & 0 & 0 & 0 & 1 & 0 & 0 \\
1 & 0 & 0 & 1 & 0 & 0 & 0 & 0 & 0 & 0 & 1 & 0 & 0 & 0 & 0 & 0 & 0 & 0 & 0 & 0 & 0 & 1 & 0 & 0 & 0 & 0 & 0 & 0 & 0 & 0 & 0 & 0 & 1 \\
2 & 0 & 0 & 0 & 0 & 1 & 0 & 0 & 0 & 0 & 0 & 0 & 0 & 0 & 0 & 0 & 1 & 0 & 0 & 1 & 0 & 0 & 0 & 0 & 0 & 0 & 1 & 0 & 0 & 0 & 0 & 0 & 0 \\
3 & 0 & 0 & 0 & 0 & 0 & 0 & 1 & 0 & 0 & 0 & 0 & 0 & 0 & 1 & 0 & 0 & 1 & 0 & 0 & 0 & 0 & 0 & 0 & 0 & 0 & 0 & 0 & 1 & 0 & 0 & 0 & 0 \\
4 & 0 & 0 & 0 & 0 & 0 & 1 & 0 & 0 & 0 & 0 & 0 & 0 & 0 & 0 & 1 & 0 & 0 & 0 & 0 & 1 & 0 & 0 & 0 & 0 & 1 & 0 & 0 & 0 & 0 & 0 & 0 & 0 \\
5 & 0 & 0 & 0 & 0 & 0 & 0 & 0 & 1 & 0 & 0 & 0 & 0 & 1 & 0 & 0 & 0 & 0 & 1 & 0 & 0 & 0 & 0 & 0 & 0 & 0 & 0 & 1 & 0 & 0 & 0 & 0 & 0 \\
6 & 0 & 1 & 0 & 0 & 0 & 0 & 0 & 0 & 0 & 0 & 1 & 0 & 0 & 0 & 0 & 0 & 0 & 0 & 0 & 0 & 0 & 0 & 0 & 1 & 0 & 0 & 0 & 0 & 1 & 0 & 0 & 0 \\
7 & 0 & 0 & 0 & 1 & 0 & 0 & 0 & 0 & 1 & 0 & 0 & 0 & 0 & 0 & 0 & 0 & 0 & 0 & 0 & 0 & 0 & 1 & 0 & 0 & 0 & 0 & 0 & 0 & 0 & 0 & 1 & 0
\end{tabular}

\begin{tabular}{c|llllllllllllllllllllllllllllllll}
\hline 32 & 33 & 34 & 35 & 36 & 37 & 38 & 39 & 40 & 41 & 42 & 43 & 44 & 45 & 46 & 47 & 48 & 49 & 50 & 51 & 52 & 53 & 54 & 55 & 56 & 57 & 58 & 59 & 60 & 61 & 62 & 63 \\
\hline 0 & 1 & 0 & 0 & 0 & 0 & 0 & 0 & 0 & 0 & 1 & 0 & 0 & 0 & 0 & 0 & 0 & 0 & 0 & 0 & 0 & 0 & 0 & 1 & 0 & 0 & 0 & 0 & 1 & 0 & 0 & 0 \\
0 & 0 & 0 & 1 & 0 & 0 & 0 & 0 & 1 & 0 & 0 & 0 & 0 & 0 & 0 & 0 & 0 & 0 & 0 & 0 & 0 & 1 & 0 & 0 & 0 & 0 & 0 & 0 & 0 & 0 & 1 & 0 \\
0 & 0 & 0 & 0 & 0 & 1 & 0 & 0 & 0 & 0 & 0 & 0 & 0 & 0 & 1 & 0 & 0 & 0 & 0 & 1 & 0 & 0 & 0 & 0 & 1 & 0 & 0 & 0 & 0 & 0 & 0 & 0 \\
0 & 0 & 0 & 0 & 0 & 0 & 0 & 1 & 0 & 0 & 0 & 0 & 1 & 0 & 0 & 0 & 0 & 1 & 0 & 0 & 0 & 0 & 0 & 0 & 0 & 0 & 1 & 0 & 0 & 0 & 0 & 0 \\
0 & 0 & 0 & 0 & 1 & 0 & 0 & 0 & 0 & 0 & 0 & 0 & 0 & 0 & 0 & 1 & 0 & 0 & 1 & 0 & 0 & 0 & 0 & 0 & 0 & 1 & 0 & 0 & 0 & 0 & 0 & 0 \\
0 & 0 & 0 & 0 & 0 & 0 & 1 & 0 & 0 & 0 & 0 & 0 & 0 & 1 & 0 & 0 & 1 & 0 & 0 & 0 & 0 & 0 & 0 & 0 & 0 & 0 & 0 & 1 & 0 & 0 & 0 & 0 \\
1 & 0 & 0 & 0 & 0 & 0 & 0 & 0 & 0 & 0 & 0 & 1 & 0 & 0 & 0 & 0 & 0 & 0 & 0 & 0 & 0 & 0 & 1 & 0 & 0 & 0 & 0 & 0 & 0 & 1 & 0 & 0 \\
0 & 0 & 1 & 0 & 0 & 0 & 0 & 0 & 0 & 1 & 0 & 0 & 0 & 0 & 0 & 0 & 0 & 0 & 0 & 0 & 1 & 0 & 0 & 0 & 0 & 0 & 0 & 0 & 0 & 0 & 0 & 1
\end{tabular}

One can see that all difference propagations are with prop ratio 1 . For example, the input differences $000010(=2), 001001(=9), 010100(=20)$, 
011111 (= 31), 100011 (= 35), 101000 (= 40), 110101 (= 53), 111110 (=62), always propagate to output difference $001(=1)$. The correlation matrix is:

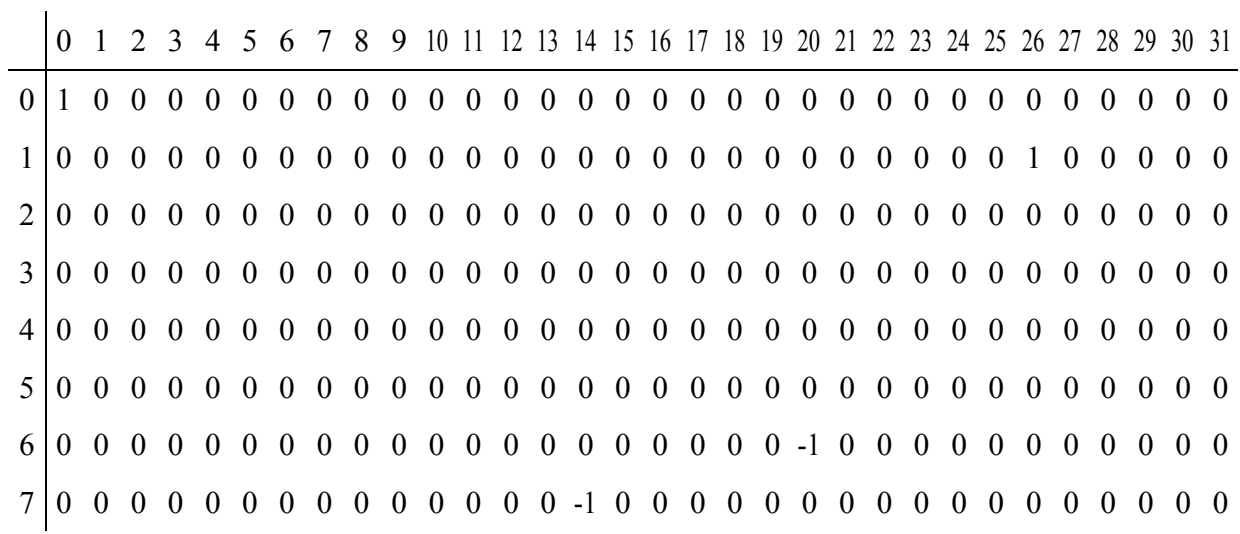

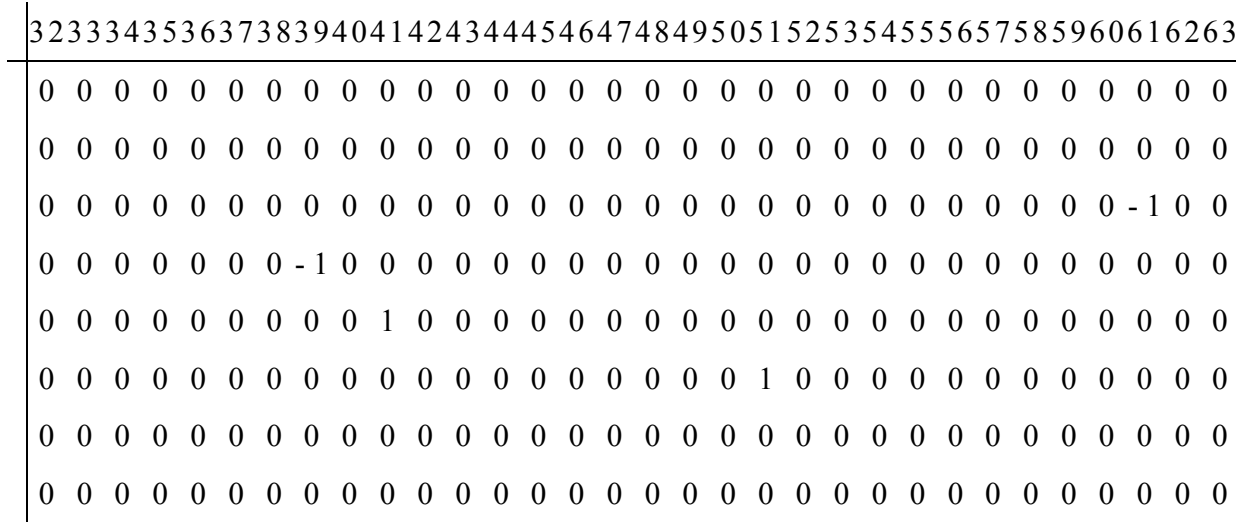

Every nonzero output selection vector is correlated only to one input selection vector with correlation 1 or -1 . For example, the output selection vector $(001)=1$ is correlated with input selection vector $(011010)=26$ with correlation 1, which means that the output bit $y_{2}$ is $y_{2}=x_{1} \oplus x_{2} \oplus x_{4}$. The output selection vector $(010)=2$ is correlated with input selection vector $(111101)=61$ with correlation -1 , which means that the output bit $y_{1}$ is $y_{1}=1 \oplus x_{0} \oplus x_{1} \oplus x_{2} \oplus x_{3} \oplus x_{5}$. This means that the every output bit can be represented by an affine function from the input bits. So, the representation of this quasigroup with $\mathrm{ANF}$ is

$h\left(x_{0}, x_{1}, x_{2}, x_{3}, x_{4}, x_{5}\right)=\left(x_{0} \oplus x_{2} \oplus x_{5}, 1 \oplus x_{0} \oplus x_{1} \oplus x_{2} \oplus x_{3} \oplus x_{5}, x_{1} \oplus x_{2} \oplus x_{4}\right)$. 


\section{CONCLUSIONS}

The quasigroups constructed from complete mappings of the groups $\left(\mathrm{Z}_{2}^{n}, \oplus_{n}\right)$ are examined in this paper. The analyze show that all of them are Shroeder's quasigroups, anti-commutative, non-associative and without left nor right unit. If a complete mapping is affine, the corresponding quasigroup is TAquasigroup. If $\theta(0)=0$, the quasigroup is idempotent.

There are 384 complete mappings for group $\left(Z_{2}^{3}, \oplus\right)$. Only 48 of constructed quasigroups are idempotent. From their prop ratio tables and correlation matrices we can conclude that all of them are linear quasigroups. If they are represented as vector valued Boolean functions, every bit of the output is represented as affine function of input bits. They can not be used as nonlinear building blocks in cryptography, but they can be used in places where linear building blocks are needed.

\section{REFERENCES}

[1] Belousov V. D. (1967), Osnovi teorii kvazigrup i lup, "Nauka", Moskva.

[2] Biham E., Shamir A. (1990), Differential Cryptanalysis of DES-like Cryptosystems, Advances in Cryptology, EUROCRYPT 1990, p. 2-21.

[3] Bruck R. H. (1944), Simple quasigroups, Bull. Amer. Math. Soc. 50, p. 769-781.

[4] Daemen J. (1995), Cipher and Hash Function Design. Strategies based on Linear and Differential Cryptanalysis, $\mathrm{PhD}$ thesis, Katholieke Universiteit Leuven.

[5] Daemen J., Govaerts R., Vandewalle J. (1995), Correlation matrices, Fast Software Encryption 1994, LNCS 1008, Springer-Verlag, p. 275-285.

[6] Damm H. M. (2007), Totally anti-symmetric quasigroups for all orders $n \neq 2,6$, Discrete Mathematics 307-6, p. 715-729.

[7] Gligoroski D., Dimitrova V., Markovski S. (2009), Quasigroups as Boolean functions, their equation systems and Groebner bases, short-note for RISC Book Series, Springer, "Groebner, Coding, and Cryptography", Ed. T. Mora, L. Perret, S. Sakata, M. Sala, and C. Traverso.

[8] Hall M., Paige L. J. (1955), Complete mappings of finite groups, Pacific Journal of Mathematics 5, p. 541-549.

[9] Klimov A., Shamir A. (2002), A new class of invertible mappings, Lecture Notes in Computer Science 2523, p. 470-483.

[10] Lindner C. C. (1971), The generalized singular direct product for quasigroups, Can. Math. Bull. 14, p. 61-63. 
[11] Matsui M. (1993), Linear Cryptanalysis Method for DES Cipher, Advances in Cryptology, EUROCRYPT 1993, p. 386-397.

[12] Meyer K. A. (2006): A new message authentication code based on the non-associativity of quasigroups, Ph.D. dissertation, Iowa State University.

[13] Paige L. J. (1947), A note on finite abelian groups, Bull. Amer. Math. Soc. 53, p. $590-593$.

[14] Paige L. J. (1951), Complete mappings of finite groups, Pacific Journal of Mathematics 1, p. 111-116.

[15] Sade A. (1957), Quasigroups automorphes par le groupe cyclique, Canadian Journal of Mathematics 9, p. 321-335.

[16] Sade A. (1960), Produit direct singulier de quasigroups orthogonaux et antiab'eliens, Ann. Soc. Sci. Bruxelles Ser. I, 74, p. 91-99.

[17] Wilson R. L. (1975), Quasidirect products of quasigroups, Commun. Algebra 3, p. $835-850$.

\section{APPENDIX A}

Here is a list of all complete mappings of the group $\left(Z_{2}^{3}, \oplus\right) .102463$

175 means complete mapping with number 1 that maps $0 \rightarrow 0,1 \rightarrow 2,2 \rightarrow 4$, $3 \rightarrow 6,4 \rightarrow 3,5 \rightarrow 1,6 \rightarrow 7$ and $7 \rightarrow 5$

$\begin{array}{rllll}102463175 & 1704153726 & 3306172435 & 4912473065 \\ 202465713 & 1804156273 & 3406175342 & 5012476530 \\ 302571346 & 1904372615 & 3506351724 & 5112560347 \\ 402576431 & 2004376251 & 3606357142 & 5212564703 \\ 502641375 & 2104512673 & 3706421753 & 5312653047 \\ 602645731 & 2204517326 & 3806427135 & 5412654730 \\ 702753146 & 2304623751 & 3906712453 & 5512740365 \\ 802756413 & 2404627315 & 4006715324 & 5612746503 \\ 903471256 & 2505142736 & 4107163425 & 5713460257 \\ 1003475612 & 2605146372 & 4207165243 & 5813467520 \\ 1103562174 & 2705362714 & 4307341625 & 5913572064 \\ 1203567421 & 2805367241 & 4407346152 & 6013574602 \\ 1303651274 & 2905413672 & 4507521643 & 6113642057 \\ 1403657412 & 3005417236 & 4607526134 & 6213647502 \\ 1503742156 & 3105723641 & 4707613452 & 6313750264 \\ 1603745621 & 3205726314 & 4807615234 & 6413754620\end{array}$

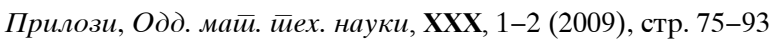


6514053627 6614057263 6714273605 6814276350 6914502763 7014506327 7114632750 7214637205 7315042637 7415047362 7515263704

7615267340 7715403762

7815406237 7915732640 8015736204 8116072534 8216074352 8316250734 8416257043 8516430752 8616437025 8716702543 8816704325 8917063524 9017064253 9117240635 9217246053 9317530642 9417536024 9517603542 9617604235 9720463157 9820467513 9920571364 10020574631 10120641357 10220647531 10320753164 10420754613
10521473056 10621475630 10721560374 10821567403 10921653074 11021657430 11121740356 11221745603 11324173506 11424175360 11524350617 11624357160 11724530671 11824537106 11924603571 12024605317 12125163407 12225164370 12325341607 12425347061 12525431670 12625437016 12725703461 12825704316 12926150437 13026154073 13126371504 13226374051 13326401573 13426405137 13526730451 13626735104 13727140536 13827145063 13927360514 14027364150 14127501463 14227504136 14327631450 14427635014
14530471265 14630476512 14730562147 14830564721 14930651247 15030654712 15130742165 15230746521 15331460275 15431465720 15531572046 15631576402 15731642075 15831645702 15931750246 16031756420 16134072516 16234075261 16334250716 16434256170 16534520761 16634526107 16734612570 16834615207 16935062417 17035064271 17135241706 17235246071 17335421760 17435426017 17535712460 17635714206 17736051427 17836054172 17936271405 18036275041 18136410572 18236415027 18336720541 18436724105
18537041526 18637045162 18737260415 18837265140 18937510462 19037514026 19137621540 19237624015 19340153762 19440156237 19540263751 19640267315 19740512637 19840517362 19940732615 20040736251 20141053672 20241057236 20341362750 20441367205 20541502736 20641506372 20741723605 20841726350 20942063571 21042065317 21142351760 21242356017 21342531706 21442536071 21542713506 21642715360 21743162570 21843165207 21943251670 22043257016 22143521607 22243527061 22343702516 22443705261 


\begin{tabular}{|c|c|c|c|}
\hline 460 & 5 & 305620 & 3 \\
\hline 646027531 & 26653174206 & 30662045137 & 346710 \\
\hline 46132075 & 26753240671 & 30762371540 & 34771350642 \\
\hline 346135702 & 26853247106 & 30862374015 & 34871356024 \\
\hline 2946201375 & 26953420617 & 30962510437 & 34971420635 \\
\hline 3046205731 & 27053427160 & 31062514073 & 35071426053 \\
\hline 3146312057 & 27153602417 & 31162730415 & 35171602435 \\
\hline 3246317502 & 27253604271 & 31262735140 & 35271605342 \\
\hline 3347031256 & 27356032174 & 31363140572 & 35372051463 \\
\hline 23447035612 & 27456037421 & 31463145027 & 35472054136 \\
\hline 3547123065 & 27556120347 & 31563271450 & 35572360541 \\
\hline 23647126530 & 27656124703 & 31663275014 & 35672364105 \\
\hline 23747213056 & 27756210374 & 31763501427 & 35772410536 \\
\hline 23847215630 & 27856217403 & 31863504172 & 35872415063 \\
\hline 23947301265 & 27956302147 & 31963720514 & 35972631405 \\
\hline 24047306512 & 28056304721 & 32063724150 & 36072635041 \\
\hline 24150142763 & 28157023164 & 32164023157 & 150462 \\
\hline 24250146327 & 28257024613 & 32264027513 & 36273154026 \\
\hline 24350273641 & 28357130246 & 32364130275 & 36373260451 \\
\hline 24450276314 & 28457136420 & 32464135720 & 36473265104 \\
\hline 24550413627 & 28557203146 & 32564203175 & 36573401526 \\
\hline 24650417263 & 28657206413 & 32664205713 & 36673405162 \\
\hline 24750632714 & 28757310264 & 32764310257 & 36773621504 \\
\hline 24850637241 & 28857314620 & 32864317520 & 36873624051 \\
\hline 24951042673 & 28960173542 & 32965031274 & 36974032156 \\
\hline 25051047326 & 29060174235 & 33065037412 & 37074035621 \\
\hline 25151372640 & 29160241753 & 33165123047 & 37174120365 \\
\hline 25251376204 & 29260247135 & 33265124730 & 37274126503 \\
\hline 25351403726 & 29360531724 & 33365213074 & 37374210356 \\
\hline 25451406273 & 29460537142 & 33465217430 & 37474215603 \\
\hline 25551623704 & 29560713524 & 33565301247 & 37574302165 \\
\hline 25651627340 & 29660714253 & 33665304712 & 37674306521 \\
\hline 25752073461 & 29761073452 & 33770162543 & 37775021364 \\
\hline 25852074316 & 29861075234 & 33870164325 & 37875024631 \\
\hline 25952340761 & 29961340752 & 33970251643 & 37975132046 \\
\hline 26052346107 & 30061347025 & 34070256134 & 38075136402 \\
\hline 26152430716 & 30161520734 & 34170431625 & 38175201346 \\
\hline 26252436170 & 30261527043 & 34270436152 & 38275206431 \\
\hline 26352613407 & 30361703425 & 34370612534 & 38375312064 \\
\hline 26452614370 & 30461705243 & 34470614352 & 38475314602 \\
\hline
\end{tabular}




\section{APPENDIX B}

Quasigroups are represented in a form

$$
\text { No. } C\left(100, z_{0}\right) \quad z_{0} \quad C\left(010, z_{1}\right) \quad z_{1} \quad C\left(001, z_{2}\right) \quad z_{2}
$$

where $C\left(100, z_{0}\right)$ is the correlation coefficient between input selection vector 100 and output selection vector $\mathrm{z}_{0} . \mathrm{z}_{0}$ is output selection vector in integer representation and it is used for representing output bit $\mathrm{y}_{0}$ as an affine function of input bits. $\mathrm{C}\left(010, \mathrm{z}_{1}\right)$ is correlation coefficient between input selection vector 010 and output selection vector $z_{1} . z_{1}$ is output selection vector in integer representation and it is used for representing output bit $\mathrm{y}_{1}$ as an affine function of input bits. $\mathrm{C}\left(001, \mathrm{z}_{2}\right)$ is correlation coefficient between input selection vector 001 and output selection vector $Z_{2} . Z_{2}$ is output selection vector in integer representation and it is used for representing output bit $y_{2}$ as an affine function of input bits. If correlation coefficient is 1 , the function is linear, and if is -1 , the function is affine.

So, 1122147137 means quasigroup constructed from the complete mapping with number $1\left(\begin{array}{lll}0 & 2463175\end{array}\right)$ as $h\left(x_{0}, x_{1}, x_{2}, x_{3}, x_{4}, x_{5}\right)=$ $\left(x_{1} \oplus x_{3} \oplus x_{4}, x_{0} \oplus x_{2} \oplus x_{3} \oplus x_{4} \oplus x_{5}, x_{0} \oplus x_{3} \oplus x_{5}\right)$ because $22=010110,47$ $=101111$ and $37=100101$.

$178141-152-162$ means quasigroup constructed from the complete mapping with number $178(36054172)$ as $h\left(x_{0}, x_{1}, x_{2}, x_{3}, x_{4}, x_{5}\right)=$ $\left(x_{0} \oplus x_{2} \oplus x_{5}, 1 \oplus x_{0} \oplus x_{1} \oplus x_{3}, 1 \oplus x_{0} \oplus x_{1} \oplus x_{2} \oplus x_{3} \oplus x_{4}\right)$ because $41=101001$, $52=110100$ and $62=111110$.

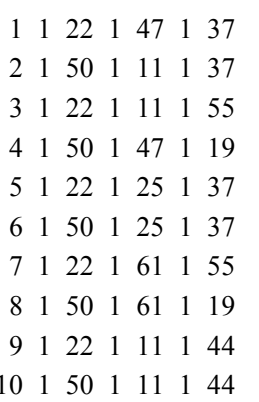

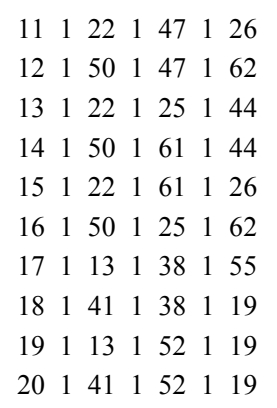

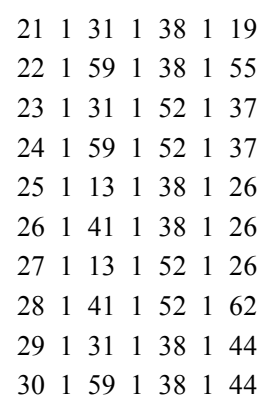

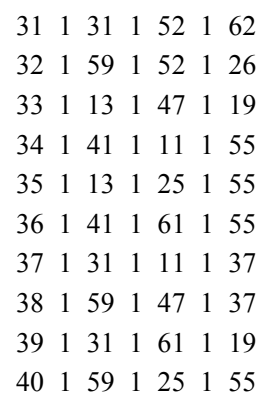




\begin{tabular}{|c|c|c|c|}
\hline $\begin{array}{llllllll}1 & 1 & 13 & 1 & 47 & 1 & 6\end{array}$ & $\begin{array}{lllllll}86 & 1 & 59 & 1 & 47 & -1 & 26\end{array}$ & $\begin{array}{lllllll}131 & 1 & 13 & -1 & 38 & 1 & 55\end{array}$ & $\begin{array}{llllll}176 & 1 & 59 & -1 & 47 & -1\end{array}$ \\
\hline $\begin{array}{lllllll}42 & 1 & 41 & 1 & 11 & 1 & 62\end{array}$ & $\begin{array}{lllllll}87 & 1 & 31 & 1 & 61 & -1 & 44\end{array}$ & $\begin{array}{lllllll}132 & 1 & 41 & -1 & 38 & 1 & 19\end{array}$ & $\begin{array}{lllllll}177 & 1 & 13 & -1 & 52 & -1 & 26\end{array}$ \\
\hline $\begin{array}{lllllll}3 & 1 & 13 & 1 & 25 & 1 & 62\end{array}$ & $\begin{array}{lllllll}88 & 1 & 59 & 1 & 25 & -1 & 44\end{array}$ & $\begin{array}{lllllll}33 & 1 & 31 & -1 & 52 & 1 & 37\end{array}$ & $\begin{array}{lllllll}178 & 1 & 41 & -1 & 52 & -1 & 62\end{array}$ \\
\hline $\begin{array}{lllllll}44 & 1 & 41 & 1 & 61 & 1 & 26\end{array}$ & $\begin{array}{lllllll}89 & 1 & 13 & 1 & 47 & -1 & 19\end{array}$ & $\begin{array}{lllllll}134 & 1 & 59 & -1 & 52 & 1 & 37\end{array}$ & $\begin{array}{lllllll}179 & 1 & 13 & -1 & 38 & -1 & 26\end{array}$ \\
\hline $\begin{array}{lllllll}45 & 1 & 3 & 1 & 11 & 1 & 62\end{array}$ & $\begin{array}{lllllll}90 & 1 & 41 & 1 & 11 & -1 & 55\end{array}$ & $\begin{array}{lllllll}135 & 1 & 31 & -1 & 38 & 1 & 19\end{array}$ & $\begin{array}{lllllll}180 & 1 & 41 & -1 & 38 & -1 & 26\end{array}$ \\
\hline $\begin{array}{lllllll}46 & 1 & 59 & 1 & 47 & 1 & 26\end{array}$ & $\begin{array}{lllllll}91 & 1 & 13 & 1 & 25 & -1 & 55\end{array}$ & $\begin{array}{lllllll}136 & 1 & 59 & -1 & 38 & 1 & 55\end{array}$ & $\begin{array}{lllllll}181 & 1 & 31 & -1 & 52 & -1 & 62\end{array}$ \\
\hline $\begin{array}{lllllll}47 & 1 & 31 & 1 & 61 & 1 & 44\end{array}$ & $\begin{array}{lllllll}92 & 1 & 41 & 1 & 61 & -1 & 55\end{array}$ & $\begin{array}{lllllll}137 & 1 & 13 & -1 & 52 & 1 & 26\end{array}$ & $\begin{array}{lllllll}182 & 1 & 59 & -1 & 52 & -1 & 26\end{array}$ \\
\hline $\begin{array}{lllllll}48 & 1 & 59 & 1 & 25 & 1 & 44\end{array}$ & $\begin{array}{lllllll}93 & 1 & 31 & 1 & 11 & -1 & 37\end{array}$ & $\begin{array}{lllllll}138 & 1 & 41 & -1 & 52 & 1 & 62\end{array}$ & $\begin{array}{lllllll}183 & 1 & 31 & -1 & 38 & -1 & 44\end{array}$ \\
\hline $\begin{array}{llllll}1 & 22 & 1 & 47 & -1 & 26\end{array}$ & $\begin{array}{lllllll}94 & 1 & 59 & 1 & 47 & -1 & 37\end{array}$ & $\begin{array}{lllllll}139 & 1 & 13 & -1 & 38 & 1 & 26\end{array}$ & $\begin{array}{lllllll}184 & 1 & 59 & -1 & 38 & -1 & 44\end{array}$ \\
\hline $\begin{array}{lllllll}50 & 1 & 50 & 1 & 47 & -1 & 62\end{array}$ & $\begin{array}{lllllll}95 & 1 & 31 & 1 & 61 & -1 & 19\end{array}$ & $\begin{array}{lllllll}140 & 1 & 41 & -1 & 38 & 1 & 26\end{array}$ & $\begin{array}{lllllll}85 & 1 & 13 & -1 & 52 & -1 & 19\end{array}$ \\
\hline $\begin{array}{lllllll}51 & 1 & 22 & 1 & 11 & -1 & 44\end{array}$ & $\begin{array}{lllllll}96 & 1 & 59 & 1 & 25 & -1 & 55\end{array}$ & $\begin{array}{lllllll}141 & 1 & 31 & -1 & 52 & 1 & 62\end{array}$ & $\begin{array}{lllllll}186 & 1 & 41 & -1 & 52 & -1 & 19\end{array}$ \\
\hline $\begin{array}{lllllll}52 & 1 & 50 & 1 & 11 & -1 & 44\end{array}$ & $\begin{array}{lllllll}97 & 1 & 22 & -1 & 25 & 1 & 37\end{array}$ & $\begin{array}{lllllll}142 & 1 & 59 & -1 & 52 & 1 & 26\end{array}$ & $\begin{array}{lllllll}187 & 1 & 13 & -1 & 38 & -1 & 55\end{array}$ \\
\hline $\begin{array}{lllllll}53 & 1 & 22 & 1 & 61 & -1 & 26\end{array}$ & $\begin{array}{lllllll}98 & 1 & 50 & -1 & 25 & 1 & 37\end{array}$ & $\begin{array}{lllllll}143 & 1 & 31 & -1 & 38 & 1 & 44\end{array}$ & $\begin{array}{lllllll}188 & 1 & 41 & -1 & 38 & -1 & 19\end{array}$ \\
\hline $\begin{array}{lllllll}54 & 1 & 50 & 1 & 25 & -1 & 62\end{array}$ & $\begin{array}{lllllll}99 & 1 & 22 & -1 & 61 & 1 & 55\end{array}$ & $\begin{array}{lllllll}144 & 1 & 59 & -1 & 38 & 1 & 44\end{array}$ & $\begin{array}{lllllll}189 & 1 & 31 & -1 & 52 & -1 & 37\end{array}$ \\
\hline $\begin{array}{lllllll}55 & 1 & 22 & 1 & 25 & -1 & 44\end{array}$ & $\begin{array}{lllllll}100 & 1 & 50 & -1 & 61 & 1 & 19\end{array}$ & $\begin{array}{lllllll}45 & 1 & 22 & -1 & 61 & -1 & 26\end{array}$ & $\begin{array}{lllllll}90 & 1 & 59 & -1 & 52 & -1 & 37\end{array}$ \\
\hline $\begin{array}{lllllll}56 & 1 & 50 & 1 & 61 & -1 & 44\end{array}$ & $\begin{array}{lllllll}101 & 1 & 22 & -1 & 47 & 1 & 37\end{array}$ & $\begin{array}{lllllll}46 & 1 & 50 & -1 & 25 & -1 & 62\end{array}$ & $\begin{array}{lllllll}191 & 1 & 31 & -1 & 38 & -1 & 19\end{array}$ \\
\hline $\begin{array}{lllllll}57 & 1 & 22 & 1 & 11 & -1 & 55\end{array}$ & $\begin{array}{lllllll}102 & 1 & 50 & -1 & 11 & 1 & 37\end{array}$ & $\begin{array}{lllllll}147 & 1 & 22 & -1 & 25 & -1 & 44\end{array}$ & $\begin{array}{lllllll}192 & 1 & 59 & -1 & 38 & -1 & 55\end{array}$ \\
\hline $\begin{array}{lllllll}58 & 1 & 50 & 1 & 47 & -1 & 19\end{array}$ & $\begin{array}{lllllll}103 & 1 & 22 & -1 & 11 & 1 & 55\end{array}$ & $\begin{array}{lllllll}148 & 1 & 50 & -1 & 61 & -1 & 44\end{array}$ & $\begin{array}{lllllll}193 & -1 & 59 & 1 & 38 & 1 & 55\end{array}$ \\
\hline $\begin{array}{lllllll}59 & 1 & 22 & 1 & 47 & -1 & 37\end{array}$ & $\begin{array}{lllllll}104 & 1 & 50 & -1 & 47 & 1 & 19\end{array}$ & $\begin{array}{lllllll}149 & 1 & 22 & -1 & 47 & -1 & 26\end{array}$ & $\begin{array}{lllllll}194 & -1 & 31 & 1 & 38 & 1 & 19\end{array}$ \\
\hline $\begin{array}{lllllll}60 & 1 & 50 & 1 & 1 & -1 & 37\end{array}$ & $\begin{array}{lllllll}105 & 1 & 22 & -1 & 25 & 1 & 44\end{array}$ & $\begin{array}{lllllll}150 & 1 & 50 & -1 & 47 & -1 & 62\end{array}$ & $\begin{array}{lllllll}195 & -1 & 59 & 1 & 52 & 1 & 37\end{array}$ \\
\hline $\begin{array}{lllllll}61 & 1 & 22 & 1 & 61 & -1 & 55\end{array}$ & $\begin{array}{lllllll}106 & 1 & 50 & -1 & 61 & 1 & 44\end{array}$ & $\begin{array}{lllllll}151 & 1 & 22 & -1 & 11 & -1 & 44\end{array}$ & $\begin{array}{lllllll}196 & -1 & 31 & 1 & 52 & 1 & 37\end{array}$ \\
\hline $\begin{array}{lllllll}62 & 1 & 50 & 1 & 61 & -1 & 19\end{array}$ & $\begin{array}{lllllll}107 & 1 & 22 & -1 & 61 & 1 & 26\end{array}$ & $\begin{array}{lllllll}52 & 1 & 50 & -1 & 11 & -1 & 44\end{array}$ & $\begin{array}{lllllll}197 & -1 & 41 & 1 & 38 & 1 & 19\end{array}$ \\
\hline $\begin{array}{lllllll}63 & 1 & 22 & 1 & 25 & -1 & 37\end{array}$ & $\begin{array}{lllllll}108 & 1 & 50 & -1 & 25 & 1 & 62\end{array}$ & $\begin{array}{lllllll}153 & 1 & 22 & -1 & 61 & -1 & 55\end{array}$ & $\begin{array}{lllllll}198 & -1 & 13 & 1 & 38 & 1 & 55\end{array}$ \\
\hline $\begin{array}{lllllll}64 & 1 & 50 & 1 & 25 & -1 & 37\end{array}$ & $\begin{array}{lllllll}109 & 1 & 22 & -1 & 11 & 1 & 44\end{array}$ & $\begin{array}{lllllll}154 & 1 & 50 & -1 & 61 & -1 & 19\end{array}$ & $\begin{array}{lllllll}199 & -1 & 41 & 1 & 52 & 1 & 19\end{array}$ \\
\hline $\begin{array}{lllllll}65 & 1 & 13 & 1 & 38 & -1 & 26\end{array}$ & $\begin{array}{lllllll}110 & 1 & 50 & -1 & 11 & 1 & 44\end{array}$ & $\begin{array}{lllllll}155 & 1 & 22 & -1 & 25 & -1 & 37\end{array}$ & $\begin{array}{lllllll}200 & -1 & 13 & 1 & 52 & 1 & 19\end{array}$ \\
\hline $\begin{array}{lllllll}66 & 1 & 41 & 1 & 38 & -1 & 26\end{array}$ & $\begin{array}{lllllll}111 & 1 & 22 & -1 & 47 & 1 & 26\end{array}$ & $\begin{array}{lllllll}156 & 1 & 50 & -1 & 25 & -1 & 37\end{array}$ & $\begin{array}{lllllll}201 & -1 & 59 & 1 & 38 & 1 & 44\end{array}$ \\
\hline $\begin{array}{lllllll}67 & 1 & 13 & 1 & 52 & -1 & 26\end{array}$ & $\begin{array}{lllllll}112 & 1 & 50 & -1 & 47 & 1 & 62\end{array}$ & $\begin{array}{lllllll}157 & 1 & 22 & -1 & 11 & -1 & 55\end{array}$ & $\begin{array}{lllllll}202 & -1 & 31 & 1 & 38 & 1 & 44\end{array}$ \\
\hline $\begin{array}{lllllll}68 & 1 & 41 & 1 & 52 & -1 & 62\end{array}$ & $\begin{array}{lllllll}113 & 1 & 13 & -1 & 25 & 1 & 55\end{array}$ & $\begin{array}{lllllll}158 & 1 & 50 & -1 & 47 & -1 & 19\end{array}$ & $\begin{array}{lllllll}203 & -1 & 59 & 1 & 52 & 1 & 26\end{array}$ \\
\hline $\begin{array}{lllllll}69 & 1 & 31 & 1 & 38 & -1 & 44\end{array}$ & $\begin{array}{lllllll}114 & 1 & 41 & -1 & 61 & 1 & 55\end{array}$ & $\begin{array}{lllllll}159 & 1 & 22 & -1 & 47 & -1 & 37\end{array}$ & $\begin{array}{ccccccc}204 & -1 & 31 & 1 & 52 & 1 & 62\end{array}$ \\
\hline $\begin{array}{lllllll}70 & 1 & 59 & 1 & 38 & -1 & 44\end{array}$ & $\begin{array}{lllllll}115 & 1 & 13 & -1 & 47 & 1 & 19\end{array}$ & $\begin{array}{lllllll}160 & 1 & 50 & -1 & 11 & -1 & 37\end{array}$ & $\begin{array}{ccccccc}205 & -1 & 41 & 1 & 38 & 1 & 26\end{array}$ \\
\hline $\begin{array}{lllllll}71 & 1 & 31 & 1 & 52 & -1 & 62\end{array}$ & $\begin{array}{lllllll}116 & 1 & 41 & -1 & 11 & 1 & 55\end{array}$ & $\begin{array}{lllllll}161 & 1 & 13 & -1 & 25 & -1 & 62\end{array}$ & $\begin{array}{lllllll}206 & -1 & 13 & 1 & 38 & 1 & 26\end{array}$ \\
\hline $\begin{array}{lllllll}72 & 1 & 59 & 1 & 52 & -1 & 26\end{array}$ & $\begin{array}{lllllll}117 & 1 & 31 & -1 & 61 & 1 & 19\end{array}$ & $\begin{array}{lllllll}162 & 1 & 4 & -1 & 61 & -1 & 26\end{array}$ & $\begin{array}{lllllll}207 & -1 & 41 & 1 & 52 & 1 & 62\end{array}$ \\
\hline $\begin{array}{lllllll}73 & 1 & 13 & 1 & 38 & -1 & 55\end{array}$ & $\begin{array}{lllllll}118 & 1 & 59 & -1 & 25 & 1 & 55\end{array}$ & $\begin{array}{lllllll}163 & 1 & 13 & -1 & 47 & -1 & 62\end{array}$ & $\begin{array}{ccccccc}208 & -1 & 13 & 1 & 52 & 1 & 26\end{array}$ \\
\hline $\begin{array}{lllllll}74 & 1 & 41 & 1 & 38 & -1 & 19\end{array}$ & $\begin{array}{lllllll}119 & 1 & 31 & -1 & 11 & 1 & 37\end{array}$ & $\begin{array}{lllllll}164 & 1 & 41 & -1 & 11 & -1 & 62\end{array}$ & $\begin{array}{lllllll}209 & -1 & 59 & 1 & 47 & 1 & 37\end{array}$ \\
\hline $\begin{array}{lllllll}75 & 1 & 13 & 1 & 52 & -1 & 19\end{array}$ & 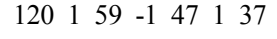 & $\begin{array}{lllllll}165 & 1 & 31 & -1 & 61 & -1 & 44\end{array}$ & $\begin{array}{lllllll}210 & -1 & 31 & 1 & 11 & 1 & 37\end{array}$ \\
\hline $\begin{array}{lllllll}76 & 1 & 41 & 1 & 52 & -1 & 19\end{array}$ & $\begin{array}{lllllll}121 & 1 & 13 & -1 & 25 & 1 & 62\end{array}$ & $\begin{array}{lllllll}166 & 1 & 59 & -1 & 25 & -1 & 44\end{array}$ & $\begin{array}{lllllll}211 & -1 & 59 & 1 & 25 & 1 & 55\end{array}$ \\
\hline $\begin{array}{lllllll}77 & 1 & 31 & 1 & 38 & -1 & 19\end{array}$ & $\begin{array}{lllllll}122 & 1 & 41 & -1 & 61 & 1 & 26\end{array}$ & $\begin{array}{lllllll}167 & 1 & 31 & -1 & 11 & -1 & 62\end{array}$ & $\begin{array}{lllllll}212 & -1 & 31 & 1 & 61 & 1 & 19\end{array}$ \\
\hline $\begin{array}{lllllll}78 & 1 & 59 & 1 & 38 & -1 & 55\end{array}$ & $\begin{array}{lllllll}123 & 1 & 13 & -1 & 47 & 1 & 62\end{array}$ & $\begin{array}{lllllll}168 & 1 & 59 & -1 & 47 & -1 & 26\end{array}$ & $\begin{array}{lllllll}213 & -1 & 41 & 1 & 11 & 1 & 55\end{array}$ \\
\hline $\begin{array}{lllllll}79 & 1 & 31 & 1 & 52 & -1 & 37\end{array}$ & $\begin{array}{lllllll}124 & 1 & 41 & -1 & 11 & 1 & 62\end{array}$ & $\begin{array}{lllllll}169 & 1 & 13 & -1 & 25 & -1 & 55\end{array}$ & $\begin{array}{lllllll}214 & -1 & 13 & 1 & 47 & 1 & 19\end{array}$ \\
\hline $\begin{array}{lllllll}80 & 1 & 59 & 1 & 52 & -1 & 37\end{array}$ & $\begin{array}{lllllll}125 & 1 & 31 & -1 & 61 & 1 & 44\end{array}$ & $\begin{array}{lllllll}170 & 1 & 41 & -1 & 61 & -1 & 55\end{array}$ & $\begin{array}{ccccccc}215 & -1 & 41 & 1 & 61 & 1 & 55\end{array}$ \\
\hline $\begin{array}{lllllll}81 & 1 & 13 & 1 & 47 & -1 & 62\end{array}$ & $\begin{array}{lllllll}126 & 1 & 59 & -1 & 25 & 1 & 44\end{array}$ & $\begin{array}{lllllll}171 & 1 & 13 & -1 & 47 & -1 & 19\end{array}$ & $\begin{array}{lllllll}216 & -1 & 13 & 1 & 25 & 1 & 55\end{array}$ \\
\hline $\begin{array}{lllllll}82 & 1 & 4 & 1 & 11 & -1 & 62\end{array}$ & $\begin{array}{lllllll}127 & 1 & 31 & -1 & 11 & 1 & 62\end{array}$ & $\begin{array}{lllllll}172 & 1 & 41 & -1 & 11 & -1 & 55\end{array}$ & $\begin{array}{lllllll}217 & -1 & 59 & 1 & 47 & 1 & 26\end{array}$ \\
\hline $\begin{array}{lllllll}83 & 1 & 13 & 1 & 25 & -1 & 62\end{array}$ & $\begin{array}{lllllll}128 & 1 & 59 & -1 & 47 & 1 & 26\end{array}$ & $\begin{array}{lllllll}173 & 1 & 31 & -1 & 61 & -1 & 19\end{array}$ & $\begin{array}{lllllll}218 & -1 & 31 & 1 & 11 & 1 & 62\end{array}$ \\
\hline $\begin{array}{lllllll}84 & 1 & 41 & 1 & 61 & -1 & 26\end{array}$ & $\begin{array}{lllllll}129 & 1 & 13 & -1 & 52 & 1 & 19\end{array}$ & $\begin{array}{lllllll}174 & 1 & 59 & -1 & 25 & -1 & 55\end{array}$ & $\begin{array}{lllllll}219 & -1 & 59 & 1 & 25 & 1 & 44\end{array}$ \\
\hline $\begin{array}{lllllll}85 & 1 & 31 & 1 & 11 & -1 & 62\end{array}$ & $\begin{array}{lllllll}130 & 1 & 41 & -1 & 52 & 1 & 19\end{array}$ & $\begin{array}{llllllll}175 & 1 & 31 & -1 & 11 & -1 & 37\end{array}$ & $\begin{array}{llllll}220 & -1 & 31 & 1 & 61 & 1\end{array}$ \\
\hline
\end{tabular}

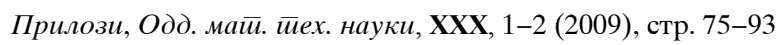




\begin{tabular}{|c|c|c|c|}
\hline $\begin{array}{llllllll}22 & -1 & 41 & 1 & 11 & 1 & 62\end{array}$ & $\begin{array}{lllllll}266 & -1 & 31 & 1 & 11 & -1 & 37\end{array}$ & $\begin{array}{lllllll}311 & -1 & 41 & -1 & 38 & 1 & 19\end{array}$ & $\begin{array}{lllllll}356 & -1 & 31 & -1 & 38 & -1 & 44\end{array}$ \\
\hline $\begin{array}{lllllll}222 & -1 & 13 & 1 & 47 & 1 & 62\end{array}$ & $\begin{array}{lllllll}267 & -1 & 59 & 1 & 25 & -1 & 55\end{array}$ & $\begin{array}{lllllll}312 & -1 & 13 & -1 & 38 & 1 & 55\end{array}$ & $\begin{array}{ccccccc}357 & -1 & 41 & -1 & 52 & -1 & 62\end{array}$ \\
\hline $\begin{array}{ccccccc}223 & -1 & 41 & 1 & 61 & 1 & 26\end{array}$ & $\begin{array}{lllllll}268 & -1 & 31 & 1 & 61 & -1 & 19\end{array}$ & $\begin{array}{lllllll}313 & -1 & 59 & -1 & 52 & 1 & 26\end{array}$ & $\begin{array}{lllllll}358 & -1 & 13 & -1 & 52 & -1 & 26\end{array}$ \\
\hline $\begin{array}{llllllll}224 & -1 & 13 & 1 & 25 & 1 & 62\end{array}$ & $\begin{array}{lllllll}269 & -1 & 41 & 1 & 11 & -1 & 55\end{array}$ & $\begin{array}{lllllll}314 & -1 & 31 & -1 & 52 & 1 & 62\end{array}$ & $\begin{array}{lllllll}359 & -1 & 41 & -1 & 38 & -1 & 26\end{array}$ \\
\hline $\begin{array}{lllllll}225 & -1 & 50 & 1 & 11 & 1 & 37\end{array}$ & $\begin{array}{lllllll}270 & -1 & 13 & 1 & 47 & -1 & 19\end{array}$ & $\begin{array}{lllllll}315 & -1 & 59 & -1 & 38 & 1 & 44\end{array}$ & $\begin{array}{lllllll}360 & -1 & 13 & -1 & 38 & -1 & 26\end{array}$ \\
\hline $\begin{array}{lllllll}226 & -1 & 22 & 1 & 47 & 1 & 37\end{array}$ & $\begin{array}{llllllll}271 & -1 & 41 & 1 & 61 & -1 & 55\end{array}$ & $\begin{array}{lllllll}316 & -1 & 31 & -1 & 38 & 1 & 44\end{array}$ & $\begin{array}{lllllll}361 & -1 & 59 & -1 & 52 & -1 & 37\end{array}$ \\
\hline $\begin{array}{lllllll}227 & -1 & 50 & 1 & 47 & 1 & 19\end{array}$ & $\begin{array}{lllllll}272 & -1 & 13 & 1 & 25 & -1 & 55\end{array}$ & $\begin{array}{lllllll}317 & -1 & 41 & -1 & 52 & 1 & 62\end{array}$ & $\begin{array}{lllllll}362 & -1 & 31 & -1 & 52 & -1 & 37\end{array}$ \\
\hline $\begin{array}{lllllll}228 & -1 & 22 & 1 & 11 & 1 & 55\end{array}$ & $\begin{array}{lllllll}273 & -1 & 50 & 1 & 47 & -1 & 62\end{array}$ & $\begin{array}{lllllll}318 & -1 & 13 & -1 & 52 & 1 & 26\end{array}$ & $\begin{array}{lllllll}363 & -1 & 59 & -1 & 38 & -1 & 55\end{array}$ \\
\hline $\begin{array}{lllllll}229 & -1 & 50 & 1 & 25 & 1 & 37\end{array}$ & $\begin{array}{llllllll}274 & -1 & 22 & 1 & 47 & -1 & 26\end{array}$ & $\begin{array}{lllllll}319 & -1 & 41 & -1 & 38 & 1 & 26\end{array}$ & $\begin{array}{lllllll}364 & -1 & 31 & -1 & 38 & -1 & 19\end{array}$ \\
\hline $\begin{array}{lllllll}230 & -1 & 22 & 1 & 25 & 1 & 37\end{array}$ & $\begin{array}{lllllll}275 & -1 & 50 & 1 & 11 & -1 & 44\end{array}$ & $\begin{array}{lllllll}320 & -1 & 13 & -1 & 38 & 1 & 26\end{array}$ & $\begin{array}{lllllll}365 & -1 & 41 & -1 & 52 & -1 & 19\end{array}$ \\
\hline $\begin{array}{lllllll}231 & -1 & 50 & 1 & 61 & 1 & 19\end{array}$ & $\begin{array}{lllllll}276 & -1 & 22 & 1 & 11 & -1 & 44\end{array}$ & $\begin{array}{lllllll}321 & -1 & 50 & -1 & 25 & 1 & 37\end{array}$ & $\begin{array}{lllllll}366 & -1 & 13 & -1 & 52 & -1 & 19\end{array}$ \\
\hline $\begin{array}{lllllll}232 & -1 & 22 & 1 & 61 & 1 & 55\end{array}$ & $\begin{array}{lllllll}277 & -1 & 50 & 1 & 25 & -1 & 62\end{array}$ & $\begin{array}{lllllll}322 & -1 & 22 & -1 & 25 & 1 & 37\end{array}$ & $\begin{array}{lllllll}367 & -1 & 41 & -1 & 38 & -1 & 19\end{array}$ \\
\hline $\begin{array}{lllllll}233 & -1 & 50 & 1 & 11 & 1 & 44\end{array}$ & $\begin{array}{llllllll}278 & -1 & 22 & 1 & 61 & -1 & 26\end{array}$ & $\begin{array}{lllllll}323 & -1 & 50 & -1 & 61 & 1 & 19\end{array}$ & $\begin{array}{lllllll}368 & -1 & 13 & -1 & 38 & -1 & 55\end{array}$ \\
\hline $\begin{array}{lllllll}234 & -1 & 22 & 1 & 11 & 1 & 44\end{array}$ & $\begin{array}{lllllll}279 & -1 & 50 & 1 & 61 & -1 & 44\end{array}$ & $\begin{array}{lllllll}324 & -1 & 22 & -1 & 61 & 1 & 55\end{array}$ & $\begin{array}{lllllll}369 & -1 & 50 & -1 & 25 & -1 & 62\end{array}$ \\
\hline $\begin{array}{lllllll}235 & -1 & 50 & 1 & 47 & 1 & 62\end{array}$ & $\begin{array}{lllllll}280 & -1 & 22 & 1 & 25 & -1 & 44\end{array}$ & $\begin{array}{lllllll}325 & -1 & 50 & -1 & 11 & 1 & 37\end{array}$ & $\begin{array}{lllllll}370 & -1 & 22 & -1 & 61 & -1 & 26\end{array}$ \\
\hline $\begin{array}{lllllll}236 & -1 & 22 & 1 & 47 & 1 & 26\end{array}$ & $\begin{array}{lllllll}281 & -1 & 50 & 1 & 47 & -1 & 19\end{array}$ & $\begin{array}{lllllll}326 & -1 & 22 & -1 & 47 & 1 & 37\end{array}$ & $\begin{array}{lllllll}371 & -1 & 50 & -1 & 61 & -1 & 44\end{array}$ \\
\hline $\begin{array}{lllllll}237 & -1 & 50 & 1 & 61 & 1 & 44\end{array}$ & $\begin{array}{lllllll}282 & -1 & 22 & 1 & 11 & -1 & 55\end{array}$ & $\begin{array}{lllllll}327 & -1 & 50 & -1 & 47 & 1 & 19\end{array}$ & $\begin{array}{lllllll}372 & -1 & 22 & -1 & 25 & -1 & 44\end{array}$ \\
\hline $\begin{array}{lllllll}238 & -1 & 22 & 1 & 25 & 1 & 44\end{array}$ & $\begin{array}{lllllll}283 & -1 & 50 & 1 & 11 & -1 & 37\end{array}$ & $\begin{array}{lllllll}328 & -1 & 22 & -1 & 11 & 1 & 55\end{array}$ & $\begin{array}{llllllll}373 & -1 & 50 & -1 & 47 & -1 & 62\end{array}$ \\
\hline $\begin{array}{lllllll}239 & -1 & 50 & 1 & 25 & 1 & 62\end{array}$ & $\begin{array}{lllllll}284 & -1 & 22 & 1 & 47 & -1 & 37\end{array}$ & $\begin{array}{lllllll}329 & -1 & 50 & -1 & 61 & 1 & 44\end{array}$ & $\begin{array}{lllllll}374 & -1 & 22 & -1 & 47 & -1 & 26\end{array}$ \\
\hline $\begin{array}{llllllll}240 & -1 & 22 & 1 & 61 & 1 & 26\end{array}$ & $\begin{array}{lllllll}285 & -1 & 50 & 1 & 61 & -1 & 19\end{array}$ & $\begin{array}{lllllll}330 & -1 & 22 & -1 & 25 & 1 & 44\end{array}$ & $\begin{array}{ccccccc}375 & -1 & 50 & -1 & 11 & -1 & 44\end{array}$ \\
\hline $\begin{array}{lllllll}241 & -1 & 59 & 1 & 38 & -1 & 44\end{array}$ & $\begin{array}{lllllll}286 & -1 & 22 & 1 & 61 & -1 & 55\end{array}$ & $\begin{array}{lllllll}331 & -1 & 50 & -1 & 25 & 1 & 62\end{array}$ & $\begin{array}{llllllll}376 & -1 & 22 & -1 & 11 & -1 & 44\end{array}$ \\
\hline $\begin{array}{lllllll}242 & -1 & 31 & 1 & 38 & -1 & 44\end{array}$ & $\begin{array}{lllllll}287 & -1 & 50 & 1 & 25 & -1 & 37\end{array}$ & $\begin{array}{lllllll}332 & -1 & 22 & -1 & 61 & 1 & 26\end{array}$ & $\begin{array}{lllllll}377 & -1 & 50 & -1 & 61 & -1 & 19\end{array}$ \\
\hline $\begin{array}{lllllll}243 & -1 & 59 & 1 & 52 & -1 & 26\end{array}$ & $\begin{array}{lllllll}288 & -1 & 22 & 1 & 25 & -1 & 37\end{array}$ & $\begin{array}{lllllll}333 & -1 & 50 & -1 & 11 & 1 & 44\end{array}$ & $\begin{array}{lllllll}378 & -1 & 22 & -1 & 61 & -1 & 55\end{array}$ \\
\hline $\begin{array}{ccccccc}244 & -1 & 31 & 1 & 52 & -1 & 62\end{array}$ & $\begin{array}{lllllll}289 & -1 & 59 & -1 & 25 & 1 & 55\end{array}$ & $\begin{array}{lllllll}334 & -1 & 22 & -1 & 11 & 1 & 44\end{array}$ & $\begin{array}{lllllll}379 & -1 & 50 & -1 & 25 & -1 & 37\end{array}$ \\
\hline $\begin{array}{lllllll}245 & -1 & 41 & 1 & 38 & -1 & 26\end{array}$ & $\begin{array}{lllllll}290 & -1 & 31 & -1 & 61 & 1 & 19\end{array}$ & $\begin{array}{lllllll}335 & -1 & 50 & -1 & 47 & 1 & 62\end{array}$ & $\begin{array}{lllllll}380 & -1 & 22 & -1 & 25 & -1 & 37\end{array}$ \\
\hline $\begin{array}{lllllll}246 & -1 & 13 & 1 & 38 & -1 & 26\end{array}$ & $\begin{array}{lllllll}291 & -1 & 59 & -1 & 47 & 1 & 37\end{array}$ & $\begin{array}{lllllll}336 & -1 & 22 & -1 & 47 & 1 & 26\end{array}$ & $\begin{array}{lllllll}381 & -1 & 50 & -1 & 47 & -1 & 19\end{array}$ \\
\hline $\begin{array}{ccccccc}247 & -1 & 41 & 1 & 52 & -1 & 62\end{array}$ & $\begin{array}{lllllll}292 & -1 & 31 & -1 & 11 & 1 & 37\end{array}$ & $\begin{array}{lllllll}337 & -1 & 59 & -1 & 25 & -1 & 44\end{array}$ & $\begin{array}{llllllll}382 & -1 & 22 & -1 & 11 & -1 & 55\end{array}$ \\
\hline $\begin{array}{lllllll}248 & -1 & 13 & 1 & 52 & -1 & 26\end{array}$ & $\begin{array}{ccccccc}293 & -1 & 41 & -1 & 61 & 1 & 55\end{array}$ & $\begin{array}{lllllll}338 & -1 & 31 & -1 & 61 & -1 & 44\end{array}$ & $\begin{array}{llllllll}383 & -1 & 50 & -1 & 11 & -1 & 37\end{array}$ \\
\hline $\begin{array}{lllllll}249 & -1 & 59 & 1 & 38 & -1 & 55\end{array}$ & $\begin{array}{lllllll}294 & -1 & 13 & -1 & 25 & 1 & 55\end{array}$ & $\begin{array}{lllllll}339 & -1 & 59 & -1 & 47 & -1 & 26\end{array}$ & $\begin{array}{lllllll}384 & -1 & 22 & -1 & 47 & -1 & 37\end{array}$ \\
\hline $\begin{array}{lllllll}250 & -1 & 31 & 1 & 38 & -1 & 19\end{array}$ & $\begin{array}{ccccccc}295 & -1 & 41 & -1 & 11 & 1 & 55\end{array}$ & $\begin{array}{lllllll}340 & -1 & 31 & -1 & 11 & -1 & 62\end{array}$ & \\
\hline $\begin{array}{lllllll}251 & -1 & 59 & 1 & 52 & -1 & 37\end{array}$ & $\begin{array}{lllllll}296 & -1 & 13 & -1 & 47 & 1 & 19\end{array}$ & $\begin{array}{lllllll}341 & -1 & 41 & -1 & 61 & -1 & 26\end{array}$ & \\
\hline $\begin{array}{lllllll}252 & -1 & 31 & 1 & 52 & -1 & 37\end{array}$ & $\begin{array}{lllllll}297 & -1 & 59 & -1 & 25 & 1 & 44\end{array}$ & $\begin{array}{lllllll}342 & -1 & 13 & -1 & 25 & -1 & 62\end{array}$ & \\
\hline $\begin{array}{lllllll}253 & -1 & 41 & 1 & 38 & -1 & 19\end{array}$ & $\begin{array}{lllllll}298 & -1 & 31 & -1 & 61 & 1 & 44\end{array}$ & $\begin{array}{lllllll}343 & -1 & 41 & -1 & 11 & -1 & 62\end{array}$ & \\
\hline $\begin{array}{lllllll}254 & -1 & 13 & 1 & 38 & -1 & 55\end{array}$ & $\begin{array}{lllllll}299 & -1 & 59 & -1 & 47 & 1 & 26\end{array}$ & $\begin{array}{lllllll}344 & -1 & 13 & -1 & 47 & -1 & 62\end{array}$ & \\
\hline $\begin{array}{ccccccc}255 & -1 & 41 & 1 & 52 & -1 & 19\end{array}$ & $\begin{array}{lllllll}300 & -1 & 31 & -1 & 11 & 1 & 62\end{array}$ & $\begin{array}{lllllll}345 & -1 & 59 & -1 & 25 & -1 & 55\end{array}$ & \\
\hline $\begin{array}{lllllll}256 & -1 & 13 & 1 & 52 & -1 & 19\end{array}$ & $\begin{array}{lllllll}301 & -1 & 41 & -1 & 61 & 1 & 26\end{array}$ & $\begin{array}{lllllll}346 & -1 & 31 & -1 & 61 & -1 & 19\end{array}$ & \\
\hline $\begin{array}{lllllll}257 & -1 & 59 & 1 & 47 & -1 & 26\end{array}$ & $\begin{array}{llllllll}302 & -1 & 13 & -1 & 25 & 1 & 62\end{array}$ & $\begin{array}{lllllll}347 & -1 & 59 & -1 & 47 & -1 & 37\end{array}$ & \\
\hline $\begin{array}{ccccccc}258 & -1 & 31 & 1 & 11 & -1 & 62\end{array}$ & $\begin{array}{llllllll}303 & -1 & 41 & -1 & 11 & 1 & 62\end{array}$ & $\begin{array}{lllllll}348 & -1 & 31 & -1 & 11 & -1 & 37\end{array}$ & \\
\hline $\begin{array}{lllllll}259 & -1 & 59 & 1 & 25 & -1 & 44\end{array}$ & $\begin{array}{lllllll}304 & -1 & 13 & -1 & 47 & 1 & 62\end{array}$ & $\begin{array}{lllllll}349 & -1 & 41 & -1 & 61 & -1 & 55\end{array}$ & \\
\hline $\begin{array}{ccccccc}260 & -1 & 31 & 1 & 61 & -1 & 44\end{array}$ & $\begin{array}{lllllll}305 & -1 & 59 & -1 & 52 & 1 & 37\end{array}$ & $\begin{array}{lllllll}350 & -1 & 13 & -1 & 25 & -1 & 55\end{array}$ & \\
\hline $\begin{array}{ccccccc}261 & -1 & 41 & 1 & 11 & -1 & 62\end{array}$ & $\begin{array}{lllllll}306 & -1 & 31 & -1 & 52 & 1 & 37\end{array}$ & $\begin{array}{lllllll}351 & -1 & 41 & -1 & 11 & -1 & 55\end{array}$ & \\
\hline $\begin{array}{lllllll}262 & -1 & 13 & 1 & 47 & -1 & 62\end{array}$ & $\begin{array}{lllllll}307 & -1 & 59 & -1 & 38 & 1 & 55\end{array}$ & $\begin{array}{lllllll}352 & -1 & 13 & -1 & 47 & -1 & 19\end{array}$ & \\
\hline $\begin{array}{ccccccc}263 & -1 & 41 & 1 & 61 & -1 & 26\end{array}$ & $\begin{array}{lllllll}308 & -1 & 31 & -1 & 38 & 1 & 19\end{array}$ & $\begin{array}{lllllll}353 & -1 & 59 & -1 & 52 & -1 & 26\end{array}$ & \\
\hline $\begin{array}{lllllll}264 & -1 & 13 & 1 & 25 & -1 & 62\end{array}$ & $\begin{array}{lllllll}309 & -1 & 41 & -1 & 52 & 1 & 19\end{array}$ & $\begin{array}{lllllll}354 & -1 & 31 & -1 & 52 & -1 & 62\end{array}$ & \\
\hline $\begin{array}{lllllll}265 & -1 & 59 & 1 & 47 & -1 & 37\end{array}$ & $\begin{array}{lllllll}310 & -1 & 13 & -1 & 52 & 1 & 19\end{array}$ & $\begin{array}{lllllll}355 & -1 & 59 & -1 & 38 & -1 & 44\end{array}$ & \\
\hline
\end{tabular}




\section{Р е $з$ и м е}

\section{КВАЗИГРУПИ КОНСТРУИРАНИ ОД КОМПЛЕТНИТЕ ПРЕСЛИКУВАЊА НА ГРУПАТА $\left(\mathrm{Z}_{2}^{n}, \oplus\right)$}

Во овој труд испитувани се квазигрупите конструирани од комплетните пресликувања на групата $\left(Z_{2}^{n} \oplus\right)$ и нивните својства како: асоцијативен закон, комутативен закон, идемпотентен закон, дали содржат потквазигрупи, дали имаат лева и десна единица, нивно претставување во алгебарска нормална форма, проп ратио табели и корелациони матрици и дали исполнуваат други идентитети. Ова е важно за нивната примена во криптографијата, теоријата на кодирање и други полиња. Како пример, ги даваме квазигрупите конструирани од 384-те комплетни пресликувања на групата $\left(Z_{2}^{3}, \oplus\right)$.

Клучни зборови: квазигрупа; комплетно пресликување; ТА-квазигрупа

Address:

\section{Aleksandra Mileva}

Faculty of Informatics, "Goce Delcev" University,

Stip, Republic of Macedonia

e-mail: Aleksandra.mileva@ugd.edu.mk

\section{Vesna Dimitrova}

Faculty of Natural Sciences and Mathematics,

"Ss. Cyril and Methodius" University in Skopje,

Republic of Macedonia

e-mail:vesnap@ii.edu.mk

Received: 26. III 2009

Accepted: 1. XII 2009 